\title{
Cytogenetic Response in Chronic Myeloid Leukaemia Patients Treated with Imatinib Mesylate Homolog-Drugs: 6 Year's Transitional Study
}

\author{
Najmaddin Khoshnaw ${ }^{1}$, Bassam Francis ${ }^{2}$, Banaz M. Safar ${ }^{1}$, Salim S. Mahmood ${ }^{3}$, \\ Beston F. Nore ${ }^{4,5}$ \\ ${ }^{1}$ Department of Haematology, Hiwa Hospital, Sulaymaniyah, Kurdistan Region, Iraq \\ ${ }^{2}$ Department of Haematology, Baghdad Teaching Hospital (Medical City), Baghdad, Iraq \\ ${ }^{3}$ Departmentof Immunology and Microbiology, Laboratory of Haematopathology and Immunology, Baghdad, \\ Iraq \\ ${ }^{4}$ Department of Biochemistry, Faculty of Medical Sciences, School of Medicine, University of Sulaimani, \\ Sulaymaniyah, Kurdistan Region, Iraq \\ ${ }^{5}$ Department of Health, Kurdistan Institution for Strategic Studies and Scientific Research, Sulaymaniyah, \\ Kurdistan Region, Iraq \\ Email: najmaddin salih@yahoo.com
}

Received 5 March 2014; revised 1 April 2014; accepted 8 April 2014

Copyright (C) 2014 by authors and Scientific Research Publishing Inc.

This work is licensed under the Creative Commons Attribution International License (CC BY).

http://creativecommons.org/licenses/by/4.0/

(c) (i) Open Access

\section{Abstract}

Background: Treatment for Chronic Myeloid Leukaemia (CML) is mainly imatinib mesylate (IM) from original-brand, Glivec ${ }^{\circledR}$ or generic-type homologs, Imatib ${ }^{\circledR}$. Materials and Methods: A collection of 149 CML patients was treated over a period of 6 years at Hiwa hospital. These patients were clustered into three groups: Group A was treated with Imatib for more than one year. All survivors of group A patients were switched to Glivec, classified as group B. Group C received only Glivec after June 2011. Imatib and Glivec are administered at doses 400-, 600- and 800-mg according to the CML stage. Results: Among group A patients, 68 (60\%) were in complete haematological response (CHR), $32(28.3 \%)$ developed acceleration and $13(11.5 \%)$ patients were deceased. After switching to Glivec (group B), 69 (69\%) patients remained in CHR, 10 (10\%) patients were deceased and $21(21 \%)$ patients remained in acceleration. Of the 36 patients in group $C, 33(91.7 \%)$ were in CHR, $1(2.8 \%)$ were in acceleration and $2(5.5 \%)$ deceased. Those patients with CHR were tested randomly for BCR/ABL by FISH, and only $1 / 25(4 \%)$ patients were found with complete cytogenetic response (CCyR) in group A, while 31/42 (73.8\%) and 13/17 (76.5\%) have CCyR in

\footnotetext{
"Corresponding author.
}

How to cite this paper: Khoshnaw, N., et al. (2014) Cytogenetic Response in Chronic Myeloid Leukaemia Patients Treated with Imatinib Mesylate Homolog-Drugs: 6 Year's Transitional Study. Journal of Cancer Therapy, 5, 453-459. 
group B and C, respectively. Conclusions: Our results demonstrate a less cytogenetic response to treatment in patients of CML, who received the Imatib therapy, while a significant cytogenetic remission was found in patients with CHR after they switched to Glivec.

\author{
Keywords \\ Chronic Myeloid Leukaemia, Glivec ${ }^{\circledR}$, Imatib ${ }^{\circledR}$, Complete Haematological Response, Cytogenetic \\ Remission
}

\title{
1. Introduction
}

Chronic myelogenous leukaemia (CML) is a clonal myeloproliferative disorder, characterized by presence of Philadelphia $(\mathrm{Ph})$ chromosome [1]-[5], which is a reciprocal translocation t (9q34; 22q11) that creates an aberrant mRNA product, leading to production of a fusion protein p210 BCR-ABL that has a constitutive tyrosine kinase (TK) activity of ABL [6]-[8]. In the past, CML had been treated with busulfan and hydroxyurea but with high rates of progression from chronic to accelerated phase and median survival of 39 to 47 months [9]. Then after, interferon alpha provided a further improvement in treatment with a complete haematological response (CHR) in $73 \%$ of patients and cytogenetic remission (CyR) in 50\%, with a significant survival advantage over busulfan [10]-[13].

Tyrosine kinase inhibitors, imatinib and/or imatinib derivatives provide specific-targeted therapy to the BCRABL fusion product and it is the first-line clinical treatment for CML patients [9] [14]. The Novartis drug imatinib mesylate, commercially recognized as Glivec ${ }^{\circledR} /$ Gleevec $^{\circledR}$, was approved by federal drug administration (FDA) in 2001 for the treatment of CML. The high frequencies of complete hematological response (CHR), cytogenetic response (CyR), and molecular remission (MR) were evident [15]. A seven-year follow-up of CML patients in the International Randomized Study of Interferon (IRIS) and ST1571 trial with imatinib mesylate have showed $81 \%$ event free survival, 86\% overall survival and low rates of transformation (7\%) [16].

In 2006, a generic imatinib mesylate, known as Imatib ${ }^{\circledR}$, appeared in the market produced by Cipla (India) and was supposed to be as efficient as Gilvec ${ }^{\circledR}$. Generic IM appeared in many developing countries, bypassing international pharmaceutical patent regulations. In Iraq, this drug has been provided for public-health sector for a period of time. However, the Iraqi health sector in 2011 displaced Imatib $^{\circledR}$ to Glivec ${ }^{\circledR}$. This transference provided an ideal opportunity to evaluate the clinical efficacy of generic and patented forms of imatinibmesylate as a retrospective transition study on patients treated at our site as a single-governmental institution, over a period of 6 years.

Although we have not found any reported data in Iraq, two cases were published in Egypt, describing therapy by shifting from Glivec to Imatib. Clearly, the data indicated a worsening of CML progression status [17]. In this work, the generic IM has been proven to decline the response after the successful Glivec ${ }^{\circledR}$ therapy [17]. In other reports, the difference in clinical efficacy has been shown between the authorized form of IM (Glivec ${ }^{\circledR}$ ) and the generic IM (Imatib) [18] [19]. The exact cause for the clinical efficacy difference is not known, but it is likely to be related to structural polymorphic forms of the drug [18].

\section{Methods}

\subsection{Patients}

A total of 149 cases of CML were diagnosed in Hiwa hospital from January 2005 through December 2012. For all cases, the complete blood count and bone marrow examination was done and FISH analysis for diagnosis of CML-fusion gene was performed on peripheral blood samples and/or bone marrow samples. In addition, the status of CML patients was defined depending on complete blood picture and ultrasound of spleen, into chronic-, accelerated- and blastic-phases according to international definitions as described in references [8] [20]-[22]. We categorize all these patients (149 individuals) into three groups: group A consisted of 113 patients who treated with Imatib for one year or more prior to June 2011. From June 2011, survivors of group A patients (100 patients) were switched to Glivec and grouped as group B. Group C (36 patients), who were diagnosed with 
CML after June 2011 and they were received only Glivec.

\subsection{Criteria for CML Treatment Response}

For all three group patients, who had CHR and are on IM medication for one year or more, FISH analysis were done to assess the cytogenetic response and the response criteria were summarized in Table 1 and Table 2 [11] [22]-[25]. Written informed consent was obtained from all patients in accordance with the amended Declaration of Helsinki 2008.

\subsection{Statistical Analysis}

For the statistical purpose the data accumulated and analyzed using Average, Ratio, Range, Chi-square method and P-value.

\section{Results}

Out of the whole patient groups, the overall male to female ratio is calculated to be 1.1. The 44-years age is the mean of the ages 10 - 85 (Figure 1). Among group A, which consist of 113 patients, 68 (60\%) patients were in CHR, 32 (28.3\%) patients developed acceleration and 13 (11.5\%) patients were deceased (Table 3). For those 68 patients with CHR, 25 patients were examined further detecting residual BCR-ABL fusion applying FISH technique. On-the-other-hand, one patient (4\%) had complete CyR, while 19 (76\%), 1 (4\%), 3 (12\%), 1 (4\%) patients had partial, minor, minimal and failure to CyR, respectively (Figure 2). After switching to Glivec (group B), 100 patients with a median of 18 months follow-up were monitored. Among group B, 69 (69\%) patients remained in CHR, 21 (21\%) patients had experience of transformation to advance stage of CML and 10 (10\%) patients were deceased. Of the 69 cases with CHR, only 42 patients tested by FISH for BCR-ABL fusion gene. The results showed 31 (73.8\%) patients with complete CyR, 4 (9.5\%) patients had partial CyR, 4 (9.5\%) patients had minor

Table 1. Criteria for the assessment of patients' status based on FISH for BCR-ABL gene analysis.

$\begin{array}{lc}\text { No cytogenetic response } & >95 \% \mathrm{Ph}+\text { metaphase CBA } \\ \text { Minimal cytogenetic response } & 95 \%-66 \% \mathrm{Ph}+\text { metaphase CBA } \\ \text { Minor cytogenetic response } & 65 \%-36 \% \mathrm{Ph}+\text { metaphase CBA } \\ \text { Partial cytogenetic response } & 1 \%-35 \% \mathrm{Ph}+\text { metaphase CBA }\end{array}$

The cytogenetic response according to percentage of $\mathrm{Ph}+$ chromosome to complete, partial, minor, and failure in CML patients tested by FISH.

Table 2. Response criteria for chronic myelogenous leukemia treatment.

\begin{tabular}{|c|c|c|c|c|}
\hline \multirow{2}{*}{$\begin{array}{c}\text { Period } \\
\text { (months) }\end{array}$} & \multicolumn{4}{|c|}{ Response Status } \\
\hline & Optimal & Sub-optimal & Failure & Warnings \\
\hline 3 & $\begin{array}{l}\text { CHR At least minor CyR } \\
\text { BCR-ABL } \leq 10 \% \text { by } \\
\text { qRT-PCR or PCyR }\end{array}$ & $\begin{array}{l}\text { No CyR } \\
\text { NA }\end{array}$ & $\begin{array}{c}<\text { CHR } \\
\text { BCR-ABL }>10 \% \text { by qRT-PCR or }<\text { PCyR } \\
\text { on BM cytogenetics }\end{array}$ & NA \\
\hline 6 & $\begin{array}{l}\text { At least PCyR } \\
\text { NA }\end{array}$ & $\begin{array}{l}<\text { PCyR } \\
\text { NA }\end{array}$ & $\begin{array}{l}\text { No CyR } \\
\text { NA }\end{array}$ & NA \\
\hline 12 & CCyR & PCyR $^{*}$ & $<$ PCyR $^{*}$ & NA \\
\hline 18 & MMR CCyR & $<$ MMR NA & $<$ CCyR & NA \\
\hline $\begin{array}{l}\text { At any time during } \\
\text { treatment }^{*}\end{array}$ & Stable or improving MMR & $\begin{array}{l}\text { Loss of MMR } \\
\text { BCR-ABL KD mutations } \\
\text { (still sensitive to imatinib) }\end{array}$ & $\begin{array}{c}\text { Loss of CHR Loss of CCyR } \\
\text { BCR-ABL KD mutations } \\
\text { (poorly sensitive to imatinib) CCA/ } \mathrm{Ph}^{+* *}\end{array}$ & $\begin{array}{c}\text { Increase in } \\
\text { transcript levels } \\
\mathrm{CCA} / \mathrm{Ph}^{-}\end{array}$ \\
\hline
\end{tabular}

The criteria are measured according to the definitions of the European Leukemia Net (ELN) and National Comprehensive Cancer Network (NCCN). The guidelines were followed with positive chronic-phase that includes the presence of Philadelphia (Ph) chromosome. PCyR, partial cytogenetic response; MMR, major molecular response; CCA, clonal chromosomal abnormalities. $\left(^{*}\right)$ ELN criteria refer to previously untreated patients with chronic phase CML who received $400 \mathrm{mg} /$ day. NCCN are those who received IM $400 \mathrm{mg} /$ day; nilotinib, $300 \mathrm{mg}$ twice daily; or dasatinib, $100 \mathrm{mg}$ daily. ( $^{* *}$ ) Clonal progression during treatment; CHR, Chronic hematological response; CCyR, Complete cytogenetic response. 
CyR, 2 (4.8\%) minimal CyR and only 1 (2.4\%) patient had failure to get CyR. Regarding group C, 33 (91.7\%) patients of 36 had CHR, 1 (2.8\%) patient with acceleration stage and 2 (5.5\%) patients were deceased. Of the 33 patients with CHR, 17 patients were tested by FISH (BCR-ABL), in which 13 (76.5\%) cases had complete CyR, 3 (17.6\%), 1 (5.9\%) case had had partial and minor CyR, respectively (Table 3 and Figure 2).

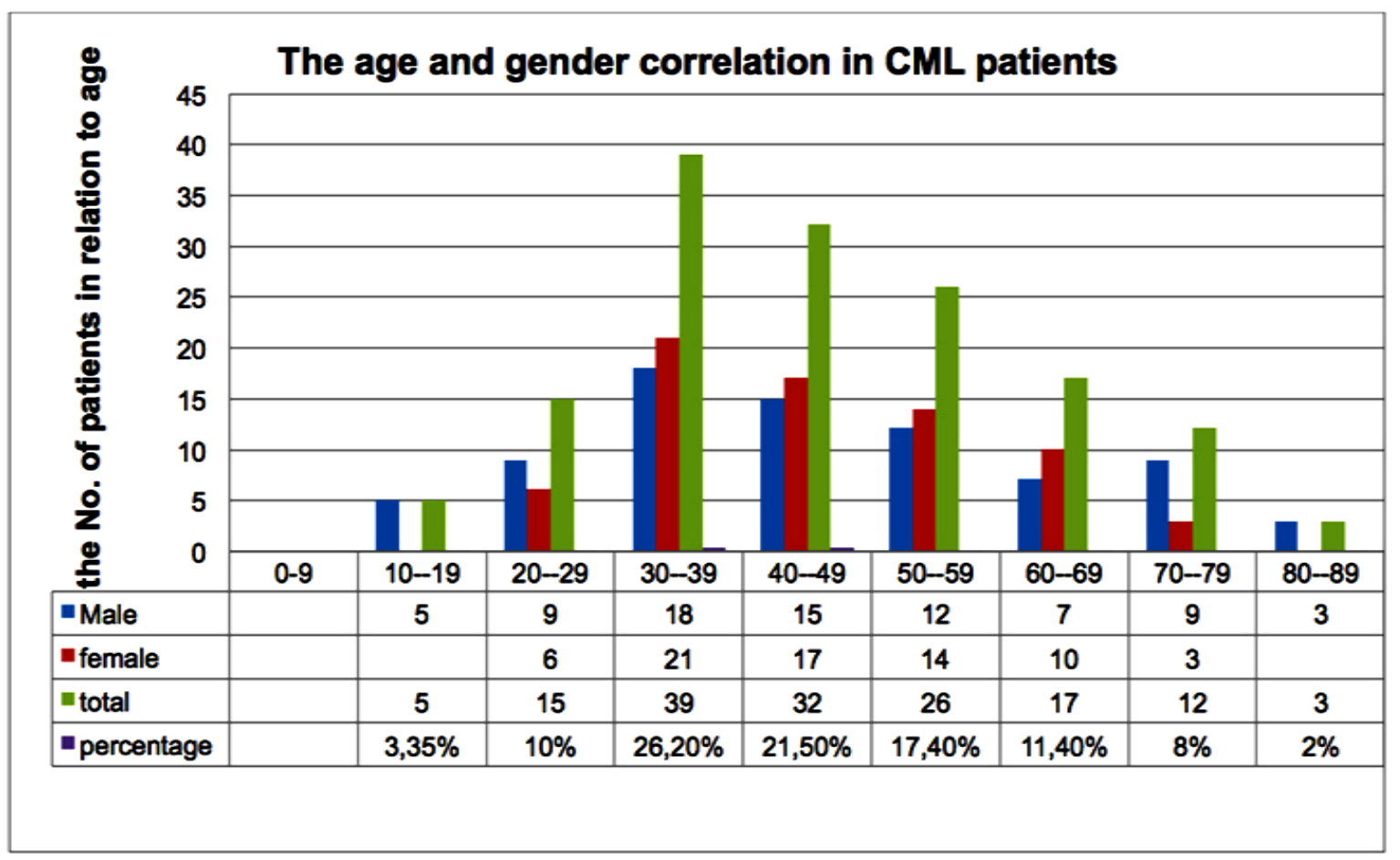

Figure 1. The age and gender distribution of all $149 \mathrm{CML}$ patients. The overall male to female ratio is calculated to be 1.1. The 44-years age is the mean of the ages 10 - 85. These patients were registered between 2005 until 2012.

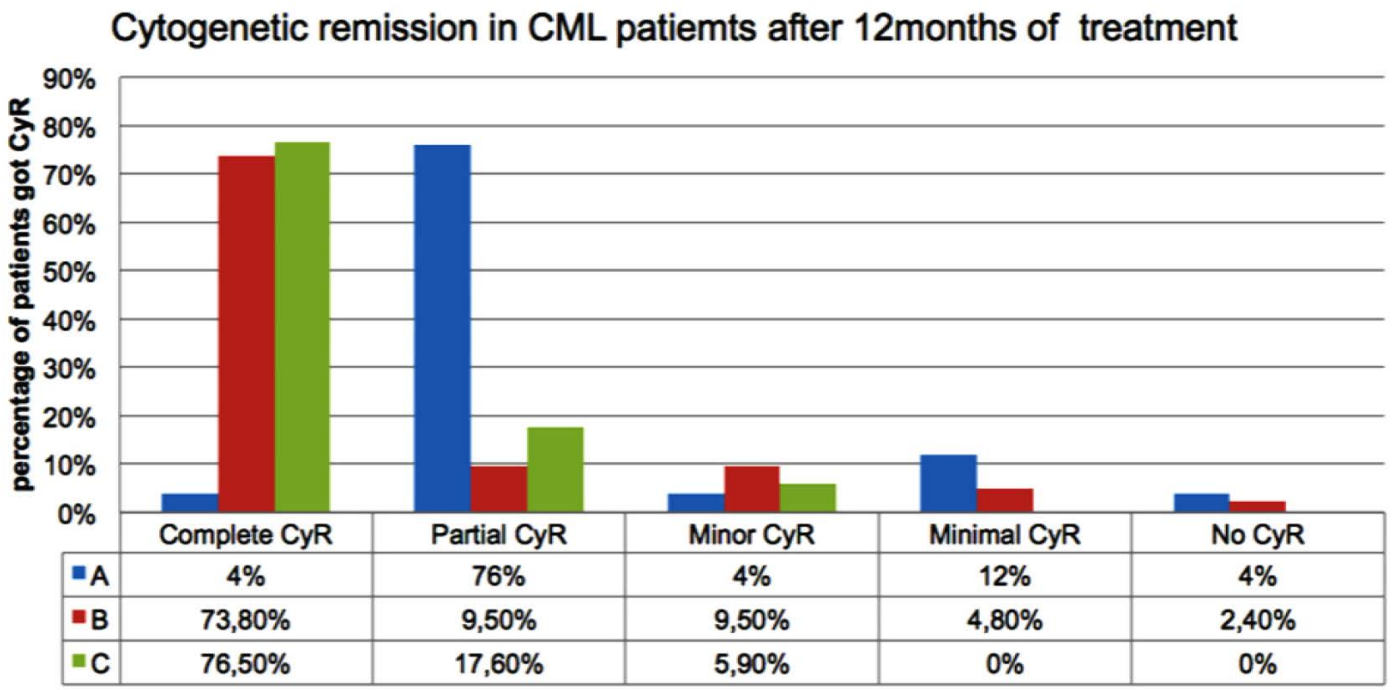

Figure 2. Cytogenetic remission in CML patient groups treated with Imatib and Glivec at 12 months of treatment. High percentage of CCyR found among group $\mathrm{C}$ patients who were randomly tested for detection of the BCR-ABL fusion by FISH technique. 
Table 3. Presentations of the patient responses following chemotherapy treatments.

\begin{tabular}{cccc}
\hline Conditions & Group A & Group B & Group C \\
\hline Complete hematological response (CHR) & $68(60 \%)$ & $69(69 \%)$ & $33(91.7 \%)$ \\
Transformation & $32(28.3 \%)$ & $21(21 \%)$ & $1(2.8 \%)$ \\
Deceased & $13(11.5 \%)$ & $10(10 \%)$ & $2(5.5 \%)$ \\
Complete cytogenetic response (CCyR) & $1(4 \%)$ & $31(73.8 \%)$ & $13(76.5 \%)$ \\
\hline
\end{tabular}

The data includes CHR, CCyR, transformation and death rate, following Imatib only (group A), Imatib and Glivec (group B) and Glivec only (group C).

\section{Discussion}

Tyrosine kinase inhibitor is a principal care to cure CML patients in Iraq. However, still the expense of therapy is an issue when we decide to choose the type of drug non-generic, generic or copy. Whatever the type of the drug applied in the treatment of CML, the best efficacy and response rate is the goal of physicians and health centers. Our data showed, a significant difference in hematological response between group A (60\%) and C (91.7\%) (Table 3). Also a significant difference in CyR rate between patients who initiated Imatib (group A) 1 (4\%) and Glivec in (group C) (76.5\%) with significant P-value of $<0.001$. We observed significant raise in response rate for CML patients, who were initiated Glivec, while the cytogenetic response for patients who started with imatib increased from $1 \%$ to $73.8 \%$ when they were shifted to Glivec. This is a clear improvement in the management response (Figure 2). Indeed, a lower rate of progression and mortality showed in group C patients who started Glivec $1(2.8 \%)$ and $2(5.5 \%)$ respectively, while in group A the progression and mortality rates were much more (28.3\%) and (11.5\%) respectively (Table 3). Consequently, this is mostly due to lower rate of complete cytogenetic response for patients started with imatib among group A and B with significant P-value $<0.001$. The exact reasons for this difference in clinical efficacy are unknown, but may be related to the use of an alternative polymorphic form of the drug. Every effort should be made to maintain patients in remission on specific medication, and careful follow-up is needed if patients who have achieved remissions are shifted to generic/copy drug. This management will ensure that the response is not compromised. Without supportive clinical evidence of efficacy and safety of this (or any other) copy product caution should be used in substitution of imatinib for CML patients in general.

\section{Conclusion}

Our study suggests a clear difference in clinical efficacy between the branded form of IM (Glivec) and generic form (Imatib). This is supported by the significant differences in cytogenetic responses among different groups with the significant higher response rate between Glivec groups. Pharmaceutical and biologic equivalence needed to be evaluated before a generic/copy product can be administered without proper clinical trial procedure to insure patient safety and determine the clinical efficacy.

\section{Competing Interests}

The authors declare no competing financial interests.

\section{Authors' Contributions}

NSHK performed all data collection, most of clinical follow-up and treatment. Designing and writing most parts of manuscript, BF observed the clinical and laboratory investigation of all patients before switching and shared in the writing the manuscript, BMS share the clinical follow-up and data collection, SSM did most of the FISH tests, BFN revised the data presentation and edited the manuscript.

\section{Acknowledgements}

We thank Dr. Rekawt Hama Rasheed (Ministry of Health, Kurdistan Regional Government) and Dr. Dossti Najat Othman director of Hiwa hospital in creating environment for research. We give our sincere gratitude to Dr. 
Michael Hughson, MD, Pathologist in Shorsh hospital in reviewing the Manuscript. We have also special thanks to all doctors, registry unit and pharmacy unit at Hiwa Hospital to assist in the data collection of the patients.

\section{References}

[1] Fialkow, P.J., Jacobson, R.J. and Papayannopoulou, T. (1977) Chronic Myelocytic Leukemia: Clonal Origin in a Stem Cell Common to the Granulocyte, Erythrocyte, Platelet and Monocyte/Macrophage. American Journal of Medicine, 63, 125-130. http://dx.doi.org/10.1016/0002-9343(77)90124-3

[2] Faderl, S., Talpaz, M., Estrov, Z., O’Brien, S., Kurzrock, R. and Kantarjian, H.M. (1999) The Biology of Chronic Myeloid Leukemia. The New England Journal of Medicine, 341, 164-172. http://dx.doi.org/10.1056/NEJM199907153410306

[3] Griffin, J.D., Todd, R.F., Ritz, J., Nadler, L.M., Canellos, G.P., Rosenthal, D., Gallivan, M., Beveridge, R.P., Weinstein, H., Karp, D., et al. (1983) Differentiation Patterns in the Blastic Phase of Chronic Myeloid Leukemia. Blood, 61, 8591.

[4] Rowley, J.D. (1973) Letter: A New Consistent Chromosomal Abnormality in Chronic Myelogenous Leukaemia Identified by Quinacrine Fluorescence and Giemsa Staining. Nature, 243, 290-293. http://dx.doi.org/10.1038/243290a0

[5] Shtivelman, E., Lifshitz, B., Gale, R.P. and Canaani, E. (1985) Fused Transcript of abl and bcr Genes in Chronic Myelogenous Leukaemia. Nature, 315, 550-554. http://dx.doi.org/10.1038/315550a0

[6] Kurzrock, R., Gutterman, J.U. and Talpaz, M. (1988) The Molecular Genetics of Philadelphia Chromosome-Positive Leukemias. The New England Journal of Medicine, 319, 990-998. http://dx.doi.org/10.1056/NEJM198810133191506

[7] Melo, J.V. (1996) The Molecular Biology of Chronic Myeloid Leukaemia. Leukemia, 10, 751-756.

[8] Sawyers, C.L. (1999) Chronic Myeloid Leukemia. The New England Journal of Medicine, 340, 1330-1340. http://dx.doi.org/10.1056/NEJM199904293401706

[9] Savage, D.G. and Antman, K.H. (2002) Imatinib Mesylate-A New Oral Targeted Therapy. The New England Journal of Medicine, 346, 683-693. http://dx.doi.org/10.1056/NEJMra013339

[10] Hochhaus, A., Lin, F., Reiter, A., Skladny, H., van Rhee, F., Shepherd, P.C., Allan, N.C., Hehlmann, R., Goldman, J.M. and Cross, N.C. (1995) Variable Numbers of BCR-ABL Transcripts Persist in CML Patients Who Achieve Complete Cytogenetic Remission with Interferon-Alpha. British Journal of Haematology, 91, 126-131. http://dx.doi.org/10.1111/j.1365-2141.1995.tb05257.x

[11] O’Brien, S.G., Guilhot, F., Larson, R.A., Gathmann, I., Baccarani, M., Cervantes, F., Cornelissen, J.J., Fischer, T., Hochhaus, A., Hughes, T., et al. (2003) Imatinib Compared with Interferon and Low-Dose Cytarabine for Newly Diagnosed Chronic-Phase Chronic Myeloid Leukemia. The New England Journal of Medicine, 348, 994-1004. http://dx.doi.org/10.1056/NEJMoa022457

[12] Hehlmann, R., Heimpel, H., Hasford, J., Kolb, H.J., Pralle, H., Hossfeld, D.K., Queisser, W., Loffler, H., Hochhaus, A., Heinze, B., et al. (1994) Randomized Comparison of Interferon-Alpha with Busulfan and Hydroxyurea in Chronic Myelogenous Leukemia. The German CML Study Group. Blood, 84, 4064-4077.

[13] Talpaz, M., Kantarjian, H., Kurzrock, R., Trujillo, J.M. and Gutterman, J.U. (1991) Interferon-Alpha Produces Sustained Cytogenetic Responses in Chronic Myelogenous Leukemia. Philadelphia Chromosome-Positive Patients. Annals of Internal Medicine, 114, 532-538. http://dx.doi.org/10.7326/0003-4819-114-7-532

[14] Druker, B.J., Tamura, S., Buchdunger, E., Ohno, S., Segal, G.M., Fanning, S., Zimmermann, J. and Lydon, N.B. (1996) Effects of a Selective Inhibitor of the Abl Tyrosine Kinase on the Growth of Bcr-Abl Positive Cells. National Medicine, 2, 561-566. http://dx.doi.org/10.1038/nm0596-561

[15] Druker, B.J., Guilhot, F., O’Brien, S.G., Gathmann, I., Kantarjian, H., Gattermann, N., Deininger, M.W., Silver, R.T., Goldman, J.M., Stone, R.M., et al. (2006) Five-Year Follow-Up of Patients Receiving Imatinib for Chronic Myeloid Leukemia. The New England Journal of Medicine, 355, 2408-2417. http://dx.doi.org/10.1056/NEJMoa062867

[16] Hughes, T.P., Hochhaus, A., Branford, S., Muller, M.C., Kaeda, J.S., Foroni, L., Druker, B.J., Guilhot, F., Larson, R.A., O’Brien, S.G., et al. (2010) Long-Term Prognostic Significance of Early Molecular Response to Imatinib in Newly Diagnosed Chronic Myeloid Leukemia: An Analysis from the International Randomized Study of Interferon and STI571 (IRIS). Blood, 116, 3758-3765. http://dx.doi.org/10.1182/blood-2010-03-273979

[17] Asfour, I.A. and Elshazly, S.A. (2009) Changing Therapy from Glivecto a "Copy” Imatinib Results in a Worsening of Chronic Myeloid Leukemia Disease Status: Two Case Reports. Cases Journal, 2, 9342. http://dx.doi.org/10.1186/1757-1626-2-9342

[18] Mattar, M. (2010) Failure of Copy Imatib (CIPLA, India) to Maintain Hematologic and Cytogenetic Responses in Chronic Myeloid Leukemia in Chronic Phase. International Journal of Hematology, 91, 104-106. http://dx.doi.org/10.1007/s12185-009-0431-1 
[19] Goubran, H.A. (2009) Failure of a Non-Authorized Copy Product to Maintain Response Achieved with Imatinib in a Patient with Chronic Phase Chronic Myeloid Leukemia: A Case Report. Journal of Medical Case Reports, 3, 7112. http://dx.doi.org/10.1186/1752-1947-3-7112

[20] Kantarjian, H.M., Dixon, D., Keating, M.J., Talpaz, M., Walters, R.S., McCredie, K.B. and Freireich, E.J. (1988) Characteristics of Accelerated Disease in Chronic Myelogenous Leukemia. Cancer, 61, 1441-1446. http://dx.doi.org/10.1002/1097-0142(19880401)61:7<1441::AID-CNCR2820610727>3.0.CO;2-C

[21] Sokal, J.E., Baccarani, M., Russo, D. and Tura, S. (1988) Staging and Prognosis in Chronic Myelogenous Leukemia. Seminars in Hematology, 25, 49-61.

[22] Kantarjian, H.M., Keating, M.J., Talpaz, M., Walters, R.S., Smith, T.L., Cork, A., McCredie, K.B. and Freireich, E.J. (1987) Chronic Myelogenous Leukemia in Blast Crisis. Analysis of 242 Patients. American Journal of Medicine, 83, 445-454. http://dx.doi.org/10.1016/0002-9343(87)90754-6

[23] Baccarani, M., Saglio, G., Goldman, J., Hochhaus, A., Simonsson, B., Appelbaum, F., Apperley, J., Cervantes, F., Cortes, J., Deininger, M., et al. (2006) Evolving Concepts in the Management of Chronic Myeloid Leukemia: Recommendations from an Expert Panel on Behalf of the European Leukemia Net. Blood, 108, 1809-1820. http://dx.doi.org/10.1182/blood-2006-02-005686

[24] Baccarani, M., Cortes, J., Pane, F., Niederwieser, D., Saglio, G., Apperley, J., Cervantes, F., Deininger, M., Gratwohl, A., Guilhot, F., et al. (2009) Chronic Myeloid Leukemia: An Update of Concepts and Management Recommendations of European Leukemia Net. Journal of Clinical Oncology, 27, 6041-6051. http://dx.doi.org/10.1200/JCO.2009.25.0779

[25] O’Brien, S., Berman, E., Borghaei, H., Deangelo, D.J., Devetten, M.P., Devine, S., Erba, H.P., Gotlib, J., Jagasia, M., Moore, J.O., et al. (2009) NCCN Clinical Practice Guidelines in Oncology: Chronic Myelogenous Leukemia. Journal of the National Comprehensive Cancer Network, 7, 984-1023. 